Review / Meta-analyses

\title{
Who are the European youths willing to engage in radicalisation? A multidisciplinary review of their psychological and social profiles
}

\author{
Nicolas Campelo ${ }^{\mathrm{a}, \mathrm{b}, \mathrm{c}, *}$, Alice Oppetit ${ }^{\mathrm{a}}$, Françoise Neau ${ }^{\mathrm{c}}$, David Cohen ${ }^{\mathrm{a}, \mathrm{d}}$, \\ Guillaume Bronsard ${ }^{\mathrm{e}, \mathrm{f}, \mathrm{g}}$ \\ a Service de Psychiatrie de l'Enfant et de l'Adolescent, Hôpital Pitié-Salpêtrière, Paris, France \\ ${ }^{\mathrm{b}}$ ARTEMIS, Atelier de Recherche, Traitement et Médiation Interculturelle et Sociale, Paris, France \\ ${ }^{c}$ Laboratoire PCPP- EA 4056, Institut de Psychologie, Université Paris V René Descartes SPC, France \\ ${ }^{\mathrm{d}}$ Institut des Systèmes Intelligents et de Robotiques, Université Pierre et Marie Curie, Paris, France \\ e CMPPD, Conseil Départemental des Bouches-du-Rhône, 45 avenue du Prado, 13006, Marseille, France \\ ${ }^{\mathrm{f}}$ Laboratoire de Santé Publique, EA3279, Aix Marseille Université, 27 bd Jean Moulin, 13005, Marseille, France, France \\ ${ }^{g}$ EA 7479, SPURBO, 22 avenue Camille Desmoulins, 29200, Brest, France
}

\section{A R T I C L E I N F O}

\section{Article history:}

Received 11 January 2018

Received in revised form 24 February 2018

Accepted 7 March 2018

Available online 31 March 2018

\section{Keywords:}

Radicalisation

Terrorism

Violent extremism

Social context

Adolescence

\begin{abstract}
A B S T R A C T
Background: A new model of radicalisation has appeared in Western countries since the 2010s. Radical groups are smaller, less hierarchical and are mainly composed of young, homegrown individuals. The aim of this review is to decipher the profiles of the European adolescents and young adults who have embraced the cause of radical Islamism and to define the role of psychiatry in dealing with this issue. Methods: We performed a systematic search in several databases from January 2010 to July 2017 and reviewed the relevant studies that included European adolescents and/or young adults and presented empirical data.

Results: In total, 22 qualitative and quantitative studies were reviewed from various fields and using different methodologies. Psychotic disorders are rare among radicalised youths. However, they show numerous risk factors common with adolescent psychopathologies. We develop a comprehensive threelevel model to explain the phenomenon of radicalisation among young Europeans: (1) individual risk factors include psychological vulnerabilities such as early experiences of abandonment, perceived injustice and personal uncertainty; (2) micro-environmental risk factors include family dysfunction and friendships with radicalised individuals; (3) societal risk factors include geopolitical events and societal changes such as Durkheim's concept of anomie. Some systemic factors are also implicated as there is a specific encounter between recruiters and the individual. The former use sectarian techniques to isolate and dehumanise the latter and to offer him a new societal model.

Conclusion: There are many similarities between psychopathological manifestations of adolescence and mechanisms at stake during the radicalisation process. As a consequence, and despite the rarity of psychotic disorders, mental health professionals have a role to play in the treatment and understanding of radical engagement among European youth. Studies with empirical data are limited, and more research should be promoted (in particular in females and in non-Muslim communities) to better understand the phenomenon and to propose recommendations for prevention and treatment.
\end{abstract}

(C) 2018 Elsevier Masson SAS. All rights reserved.

\section{Introduction}

The terrorism threat level in Europe is critical [1,2]. Terrorism is defined as the use of intentionally indiscriminate violence as a means to create terror, or fear, to achieve a political, religious or

\footnotetext{
* Corresponding author at: Service de Psychiatrie de l'Enfant et de l'Adolescent, Hôpital Pitié-Salpêtrière, Paris, France.

E-mail address: nicolas.campelo-rodriguez@aphp.fr (N. Campelo).
}

ideological aim [3]. The concept of radicalisation differs, as there is a temporal dimension: it is a process that may lead to terrorist actions. For Khosrokhavar, radicalisation is a 'process by which an individual or group adopts a violent form of action, directly linked to an extremist ideology with a social or religious political content that undermines the established political, social or cultural order' [4]. Beyond the repressive and security apparatus, many professionals and researchers from the fields of anthropology, political science, sociology, psychology and psychiatry have been involved in understanding terrorism and radicalisation. 
Attempts to explain terrorism have explored the links among Islamism, the Muslim religion, delinquency and immigration. Sageman, a psychiatrist working for the Central Intelligence Agency, showed that terrorists are educated and mostly from the upper or middle classes [5]. Several literature reviews have confirmed that there is no predefined pathway leading to radicalisation: radicalised individuals come from various backgrounds, have different origins, different family beliefs, social status or gender [6-9]. The pyramidal model of radicalisation has been widely developed. This model emphasises the idea that only a few individuals would be likely to commit a violent act after undergoing a whole step-by-step process [10-14].

However, various authors have highlighted the difference between radicalised individuals who commit violent actions within a radical group (through a maturation process such as the pyramidal model) and individuals - the 'lone wolves'- who act in a more isolated manner, who are radicalised more quickly and for whom the pyramidal model does not apply $[7,15,16]$. The latter represent only a minority of the individuals involved in terrorist activities and are more likely to suffer from psychiatric pathologies [7]. Sageman reported no indicators of mental illness among the terrorists he studied [5]. One may wonder why certain individuals are more likely than others to go through the different steps of the pyramidal model process of radicalisation. Some authors have put forward various predisposing factors, such as depressive tendencies or suicidal thoughts [17-19]. The feeling of injustice or humiliation has been also highlighted [20]. Others insist on notions of identity and belonging, emphasising that being part of a radical group and embracing a cause gives a comforting sense of a 'significance quest' around a dedication that has an 'empowerment effect' for the radicalised individual $[8,21,22]$. Moments of 'existential fragilities' have also been mentioned as elements of vulnerability that can foster radical commitment [23]. Moghaddam noted the importance of the radical group effect, together with the major influence of leaders on the individual throughout the radicalisation process [13]. Literature reviews suggest that the environmental, political, religious, social and cultural context plays an important role, making it difficult to compare the phenomenon of radicalisation from one context to another [8,14].

The studies mentioned above focus on terrorist movements of the 1990s (i.e., Al-Qaida [5,22], terrorism in the context of the Israeli-Palestinian conflict $[17,20]$ ) in which terrorists target a foreign country or are fighting for national liberation. However, the understanding of terrorist acts has changed in recent years in Europe with the emergence of 'homegrown' terrorists, born and raised in Europe, who adopt the ideology of violent radical Islamism. The recruitment methods and the methods of action have changed and given rise to new models of radicalisation. Various political scientists, sociologists and governments have made this observation. According to Sageman, the increasing use of the Internet by jihadist movements since the 2000s has led to an organisational change: today's radical groups are less organised and less centralised compared to previous hierarchical organisations such as Al-Qaida. Khosrokhavar also asserts that a new model of radicalisation has appeared in Western countries since the 2010s that is different from the pyramidal model. This new model has the following characteristics: the groups are smaller (three individuals, on average), more discrete (less proselytic), younger, and composed of more-fragile individuals who have been influenced by recruiters. Although the number of radicalised individuals remains marginal at the level of the general population, it has greatly increased since 2014 under the influence of Islamic State (IS) propaganda. In July 2014, the French Ministry of the Interior services listed 899 French people who either joined IS in Syria, returned from Syria, were on their way to Syria or said they wanted to join IS. An increase of $58 \%$ in six months was observed between
January 2014 and July 2014 [24]. In August 2016, 364 minors were registered with the French judiciary authorities by the police because of objective and worrying signs evoking a radicalisation process [25].

Existing literature reviews on radicalisation have mainly focused on adults and have scarcely explored the question of radicalised adolescents. However, since 2010, it appears that radicalised individuals in Europe are younger than they used to be (often teenagers) and that the number of young women involved is increasing [4]. How do these young people shift from a symbolic affiliation with a European country to an organisation that was originally foreign to themselves and that advocates hatred and destruction of the environment in which they grew up? We formulate the hypothesis that there are similarities between the mechanisms at stake during the radicalisation process and the psychopathological manifestations of adolescence: the attraction towards an ideal place and the rejection of their symbolic affiliation could be reflected in the issues of separation and individuation that occur during adolescence and young adulthood.

In this systematic literature review, we focused on understanding the profiles of the European adolescents and young adults who have embraced the cause of radical Islamism since the beginning of the 2010s. Various organisations have observed that the profiles of the radicalised have changed since 2010 in Europe, and this new context deserves to be examined. We searched relevant data from medical and psychological search engines and obtained articles from various fields: psychological, sociological, educational, medical and anthropological. We chose to perform a multidisciplinary review, having noted in the scientific debates that each researcher tends to reduce the comprehension of this phenomenon towards his field of knowledge thus providing an incomplete panorama of the phenomenon. This broad approach aims to make a comprehensive inventory in order to return afterwards to a more specific psychiatric or psychological approach.

\section{Methods}

We performed a search in the PubMed, PsycINFO and Psychology and Behavioural Sciences Collection databases from January 2010 to July 2017. All papers containing the terms 'Radicali"' or 'Terror"' or 'Violent Protest' in the abstract AND 'Adolescen*' or 'Juvenil"' or 'Teen"' or 'Youth' or 'Young People' or 'Young Person' in the text were identified. Moreover, the French database from the MIVILUDES (Mission interministerielle de vigilance et de lutte contre les dérives sectaires for Inter-ministry mission of vigilance and fight against sectarian activities) was screened in order to identify relevant French articles on radicalisation. Because of its experience with sectarian hold, the MIVILUDES was one of the first governmental organisations commissioned to study radicalisation in France, and it played a pioneering role in this field of research.

For the selection of the relevant studies, we used the following criteria: (i) the study population included adolescents and/or young adults: subjects aged between 12 and 25 at the time of the radical engagement; (ii) the subjects lived in a Western European country: the International Centre for the Study of Radicalisation and Political Violence showed that the majority of the youth who left for Syria and Irak since 2013 came from Belgium, Denmark, France, Germany, Netherlands or Great-Britain [26] (iii) the study was about radicalisation at large; (iv) the study included empirical data and not only theoretical information or views; (v) the study was recent (2010-2017). The PRISMA diagram flow (Fig. 1) maps out the number of records identified, included and excluded, and the reasons for exclusion through the different phases of the selection process. Of the selected studies, two co-authors (NC and AO) selected the relevant information independently: authors 


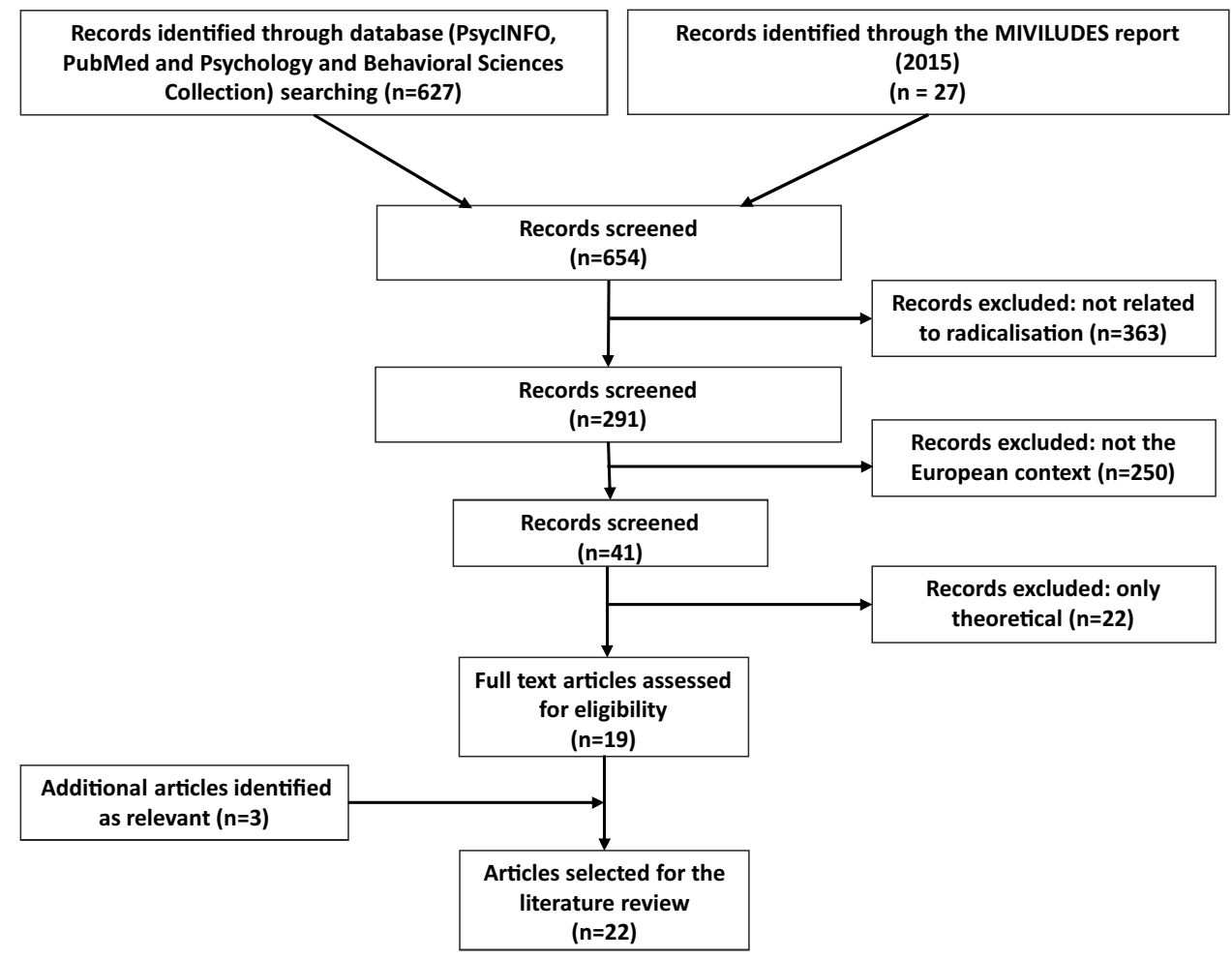

Fig. 1. The PRISMA diagram flow of the literature review.

(year), study design, the number of individuals, age ranges, gender distribution, country, radicalism criteria, features of the sample, assessment tools used in the studies, and the main findings.

\section{Results}

In total, we found 22 publications. Their main characteristics are summarised in Table 1. As expected, they came from different fields (e.g., sociology, anthropology, psychology, medecine) and used different methodologies (e.g., qualitative, quantitative). Among the 22 articles, 20 were about radicalisation related with Islam. The two remaining articles concerned affiliation to an extremist ideology or extremist group without any religious specificity or any link with Islam. Regarding the sample of interest, Table 1 distinguishes studies focusing on terrorists or individuals involved in violent actions $(n=4)$, studies focusing on individuals who intend to join the Islamic State or present extremist ideology $(n=5)$, studies focusing on adherence to radicalisation in general population samples $(n=7)$, and studies focusing on theoretical aspects based on single case reports or small series $(n=6)$. To obtain a broad view of the complex phenomenon of radicalisation, we decided to present the main results of this review according to 4 axes: (1) the different classifications that have been proposed to delineate radicalised individuals; (2) the individual risk factors of radicalisation; (3) the micro-environmental risk factors of radicalisation; and (4) the societal and cultural risk factors of radicalisation.

\subsection{Existing categorisations and typologies}

Various authors have suggested categorisations of different forms of radicalisation trying to decipher the phenomenon and to identify subgroups or profiles of interests within radicalised youths. These different categorisations are presented in Table 2. These categorisations are not comparable, because of the great variability of methodologies, approaches (criminological, sociological, anthropological) and populations from which they are developed. However, they portray the complexity of the profiles of these radicalised individuals. To detail one example: the usual categorisation used by law specialists to described terrorists, which distinguishes mainly 2 profiles (lone actor terrorist vs. group-based terrorist [16]), does not seem to fit radicalised young Europeans seen in prison contexts, where 3-4 profiles are proposed (see Table 2). Generally, these categorisations do not allow any correspondence with current classifications of mental conditions (e.g. DSM-5).

\subsection{Individual risk factors}

Psychiatric disorders are rare among radicalised youths. Individuals with a psychiatric condition represent a minority of the individuals involved in terrorist activities. Bazex and Bénézech found that only $10 \%$ of the individuals under the hand of justice for radicalisation presented a psychiatric disorder [27]. Besides, the average age of these individuals with psychiatric disorders is the highest (34 years) among the 4 categories proposed (see Table 2 , [27]). For the rest of the individuals, they note various personality traits without a formal psychiatric diagnosis: anti-social, obsessional, and histrionic traits (especially in proselytic behaviours). Rolling corroborates this finding: she reports only 3 individuals with mental disorders among the 25 included in her study [28], knowing that this study is based on a young population (13-20 years) received in child psychiatry and not necessarily known to justice for radicalisation.

In contrast, several authors describe trait vulnerabilities or psychological vulnerabilities. Several types of psychological vulnerabilities have been highlighted as risk factors for youth radicalisation. A depressive dimension is often reported among radicalised youth, with a frequent feeling of despair that does not qualify as a major depressive episode (although formal psychiatric diagnosis is not available in most studies). Radical commitment can be thought of as a way to fight against this depressivity [28,29]. For Benslama, 
Table 1

Characteristics of the studies included in the review.

\begin{tabular}{|c|c|c|c|c|c|c|c|c|c|}
\hline Author (year) & Study Design & $\mathrm{N}$ & Age & Gender & Country* & $\begin{array}{l}\text { Radicalism } \\
\text { criteria }\end{array}$ & $\begin{array}{l}\text { Features of the } \\
\text { sample }\end{array}$ & Assessment Tools & Main Findings \\
\hline \multicolumn{10}{|c|}{ Studies focusing on terrorists or individuals involved in violent actions } \\
\hline $\begin{array}{l}\text { Bazex \& } \\
\text { Mensat } \\
2016[33]\end{array}$ & $\begin{array}{l}\text { Psychological } \\
\text { profiling based on } \\
\text { judicial expertise of } \\
\text { individuals who } \\
\text { come back from Syria }\end{array}$ & 12 & $21-27$ & $\begin{array}{l}\mathrm{M} \\
(100 \%)\end{array}$ & Fra & $\begin{array}{l}\text { Went to Syria to } \\
\text { join IS }\end{array}$ & $\begin{array}{l}\text { Judicial expertise } \\
\text { because they came } \\
\text { back from Syria }\end{array}$ & $\begin{array}{l}\text { Forensic expertise } \\
\text { and psychological } \\
\text { tools }\end{array}$ & $\begin{array}{l}\text { Various clinical } \\
\text { information (lack of } \\
\text { family environment, } \\
\text { difficulties with } \\
\text { social integration, } \\
\text { importance of a } \\
\text { mentor figure and } \\
\text { religious } \\
\text { commitment outside } \\
\text { the family) and } 3 \\
\text { profiles }\end{array}$ \\
\hline $\begin{array}{l}\text { Bazex \& } \\
\text { Bénézech } \\
2017 \text { [27] }\end{array}$ & $\begin{array}{l}\text { Psychological } \\
\text { profiling based on } \\
\text { judicial expertise of } \\
\text { individuals who are } \\
\text { judicialised and } \\
\text { radicalised }\end{array}$ & 112 & Mean: 30 & $\begin{array}{l}\mathrm{M} \\
(96 \%) \\
\text { and F } \\
(4 \%)\end{array}$ & Fra & $\begin{array}{l}\text { Perceived as } \\
\text { radicalised by } \\
\text { the } \\
\text { penitentiary's } \\
\text { expert crew }\end{array}$ & $\begin{array}{l}14.3 \% \text { convictions for } \\
\text { "apology of } \\
\text { terrorism", } 10.7 \% \text { for } \\
\text { "act of terrorism" and } \\
75 \% \text { for common acts } \\
\text { of law }\end{array}$ & $\begin{array}{l}\text { Forensic expertise } \\
\text { and psychological } \\
\text { tools }\end{array}$ & $\begin{array}{l}\text { Earnings of radical } \\
\text { commitment, } \\
\text { psychological } \\
\text { invariants } \\
\text { (psychopathological } \\
\text { dimensions and } \\
\text { weakening factors) } \\
\text { and } 4 \text { new profiles } \\
\text { that show a minority } \\
\text { (10\%) of mentally ill } \\
\text { people }\end{array}$ \\
\hline Bhui 2012 [48] & $\begin{array}{l}\text { Proposition based on } \\
\text { the observation of } \\
\text { individuals who have } \\
\text { committed recent } \\
\text { terrorist attacks and } \\
\text { the counterterrorism } \\
\text { approach adopted in } \\
\text { the UK as a result }\end{array}$ & NA & NA & NA & UK & NA & $\begin{array}{l}\text { Individuals who have } \\
\text { committed recent } \\
\text { terrorist attacks }\end{array}$ & Questionnaires & $\begin{array}{l}\text { Proposition of a } \\
\text { public health } \\
\text { research and practice } \\
\text { to guard against } \\
\text { violent radicalisation }\end{array}$ \\
\hline $\begin{array}{l}\text { Schuurman } \\
2016 \text { [42] }\end{array}$ & $\begin{array}{l}\text { Literature } \\
\text { review }+ \text { analysis of } \\
\text { data from the } \\
\text { Hofstadgroup: data } \\
\text { from Dutch Police } \\
\text { files }+3 \text { interviews } \\
\text { with members of the } \\
\text { group }\end{array}$ & 3 & NA & $\begin{array}{l}M \\
(100 \%)\end{array}$ & Net & $\begin{array}{l}\text { Members of the } \\
\text { terrorist group } \\
\text { "Hofstadgroup" }\end{array}$ & $\begin{array}{l}\text { Multiplicity of the } \\
\text { socio-economic } \\
\text { backgrounds and } \\
\text { ethnic origins of the } \\
\text { group members }\end{array}$ & $\begin{array}{l}\text { Files put together by } \\
\text { the Dutch national } \\
\text { police during } \\
\text { investigation into the } \\
\text { Hofstadgroup and } \\
\text { two semi-structured } \\
\text { interviews with } \\
\text { former Hofstadgroup } \\
\text { participants. }\end{array}$ & $\begin{array}{l}\text { Most militant } \\
\text { participants' } \\
\text { rationales for } \\
\text { terrorist violence } \\
\text { were predominantly } \\
\text { personal and not } \\
\text { necessarily or } \\
\text { exclusively tied to } \\
\text { their extremist } \\
\text { religious convictions. }\end{array}$ \\
\hline \multicolumn{10}{|c|}{ Studies focusing on individuals who intend to join the Islamic State or who present an extremist ideology } \\
\hline $\begin{array}{l}\text { Bouzar } 2014 \\
{[46]}\end{array}$ & $\begin{array}{l}\text { Observations and } \\
\text { theoretical } \\
\text { conclusions based on } \\
\text { an action-research } \\
\text { project promoted by } \\
\text { the French } \\
\text { government to fight } \\
\text { radicalisation }\end{array}$ & 160 & $15-28$ & NA & Fra & $\begin{array}{l}\text { Tried to join the } \\
\text { Islamic State in } \\
\text { Syria }\end{array}$ & $\begin{array}{l}\text { The family of the } \\
\text { radicalised individual } \\
\text { contacted the CPDSI } \\
\text { to ask for help }\end{array}$ & $\begin{array}{l}\text { Qualitative } \\
\text { anthropology }\end{array}$ & $\begin{array}{l}\text { Great variability in } \\
\text { profiles; Description } \\
\text { of sophisticated and } \\
\text { personalised } \\
\text { recruitment method } \\
\text { through internet by } \\
\text { ISIS; } \\
\text { Description of } \\
\text { different steps in the } \\
\text { process of } \\
\text { radicalisation }\end{array}$ \\
\hline $\begin{array}{l}\text { Bouzar \& } \\
\quad \text { Martin } 2016 \\
\text { [30] } \\
\text { Bouzar } 2017 \\
\text { [45] } \\
\text { (Same } \\
\text { Sample) }\end{array}$ & $\begin{array}{l}\text { Observations and } \\
\text { theoretical } \\
\text { conclusions based on } \\
\text { an action-research } \\
\text { project promoted by } \\
\text { the French } \\
\text { government to fight } \\
\text { radicalisation }\end{array}$ & 809 & $12-30$ & $\begin{array}{l}\mathrm{M} \\
(40 \%) \\
\text { and } \mathrm{F} \\
(60 \%)\end{array}$ & Fra & $\begin{array}{l}\text { Tried to join the } \\
\text { Islamic State in } \\
\text { Syria }\end{array}$ & $\begin{array}{l}\text { Individuals whom the } \\
\text { CPDSI took charge of } \\
\text { after the police and/ } \\
\text { or the parents } \\
\text { prevented them from } \\
\text { leaving to enter ISIS } \\
\text { territory }\end{array}$ & $\begin{array}{l}\text { Qualitative } \\
\text { anthropology } \\
\text { focusing on } \\
\text { motivation to join IS }\end{array}$ & $\begin{array}{l}8 \text { profiles of motives } \\
\text { for radical } \\
\text { commitment are } \\
\text { described (Bouzar \& } \\
\text { Martin, 2016) } \\
\text { Illustration of how } \\
\text { ISIS recruiters adapt } \\
\text { to candidates' profile } \\
\text { to "help" them decide } \\
\text { to join IS (Bouzar, } \\
2017 \text { ) }\end{array}$ \\
\hline $\begin{array}{l}\text { Rolling \& } \\
\text { Corduan } \\
2017 \text { [28] }\end{array}$ & $\begin{array}{l}\text { Theoretical } \\
\text { conclusions based on } \\
\text { clinical observations } \\
\text { of radicalised } \\
\text { adolescents followed } \\
\text { in child psychiatry }\end{array}$ & 25 & $13-20$ & $\begin{array}{l}\mathrm{M} \\
(30 \%) \\
\text { and F } \\
(70 \%)\end{array}$ & Fra & $\begin{array}{l}\text { Perceived as } \\
\text { radicalised } \\
\text { according to } \\
\text { child } \\
\text { psychiatrists }\end{array}$ & $\begin{array}{l}\text { Individuals mostly } \\
\text { reported by } \\
\text { educational staff, } \\
\text { police or justice. } \\
\text { Described as being at } \\
\text { an early stage of } \\
\text { radicalisation. }\end{array}$ & $\begin{array}{l}\text { Qualitative approach } \\
\text { based on clinical } \\
\text { material from } \\
\text { individual or family } \\
\text { interviews }\end{array}$ & $\begin{array}{l}\text { Adolescence is a } \\
\text { factor of vulnerability } \\
\text { for radicalisation. } \\
\text { Description of various } \\
\text { psychopathological } \\
\text { factors: depressive } \\
\text { and narcissistic } \\
\text { fragilities, occasional } \\
\text { presence of PTSD } \\
\text { (post-traumatic } \\
\text { stress disorder), }\end{array}$ \\
\hline
\end{tabular}


Table 1 (Continued)

\begin{tabular}{|c|c|c|c|c|c|c|c|c|}
\hline Author (vear) & Study Design & $\mathrm{N}$ & Age & Gender & Country* & Radicalism & Features of the & Assessment Tools \\
\hline
\end{tabular}

conversion disorder or psychotic disorder. Description of two distinct phases in the process of radicalisation: 1 soothing of the psychic suffering, 2indoctrination (selfeffacement of the subject in favour of

Van San et al. 2013 social workers and teachers and the problems they face when dealing with young people with extreme ideals.

$\begin{array}{llll}16 \quad 16-25 & \text { M } & \text { Net } & \text { Extremist } \\ & (88 \%) & & \text { comments on } \\ & \text { and F } & & \text { forums } \\ & & \end{array}$

(12\%)

forums

Extremist

movements of

different kinds

(radical Islam, animal

rights, extreme right)

Qualitative

ethnography

(2)

Studies focusing on adherence to radicalisation in general population samples

$\begin{array}{cl}\text { Bhui 2014a } & \text { Assessing } \\ & \text { vulnerability to } \\ & \text { violent radicalisation } \\ & \text { and investigating the } \\ & \text { role of previously } \\ & \text { reported causes (poor } \\ & \text { self-reported health, } \\ & \text { anxiety, depression, } \\ & \text { adverse life events, } \\ & \text { poverty, migration, } \\ & \text { socio-political } \\ & \text { factors ... ) }\end{array}$

M
and F
(44\%)

\section{UK}

\section{Sympathies for violent protest and terrorism as a proxy factor}

Pakistani or Bangladeshi origin, men and women of Muslim heritage living in East London and Bardford (significant Muslim population, contrasting deprivation and cultural integration with wider society)
Questionnaire

Measuring

Sympathies for Violent Radicalisation

and Terrorism (SyfoR). 16 items,

Likert scale with scores of -3 to +3 the group)

Tolerance regarding the radical discourse in the family environment. Importance of educational support to provide a counterspeech.

Sympathies for violent protest and terrorism were uncommon among men and women, aged 18-45, of Muslim heritage living in two English cities.

Sympathy was more likely to be articulated by those under 20, those in full-time education rather than employment, those born in the UK, those speaking English at home, and high earners ( $£ 75,000$ a year).

\begin{tabular}{|c|c|c|c|c|c|c|c|c|c|}
\hline $\begin{array}{l}\text { Bhui 2014b } \\
\text { [50] } \\
\text { (same } \\
\text { sample) }\end{array}$ & $\begin{array}{l}\text { Assessing } \\
\text { vulnerability to } \\
\text { violent radicalisation } \\
\text { and investigating the } \\
\text { role of depression, } \\
\text { psychosocial } \\
\text { adversity, and limited } \\
\text { social assets in } \\
\text { offering protection or } \\
\text { suggesting } \\
\text { vulnerability to the } \\
\text { process of } \\
\text { radicalisation. }\end{array}$ & 608 & $18-45$ & $\begin{array}{l}\text { M } \\
(56 \%) \\
\text { and F } \\
(44 \%)\end{array}$ & UK & $\begin{array}{l}\text { Sympathies for } \\
\text { violent protest } \\
\text { and terrorism as } \\
\text { a proxy factor }\end{array}$ & $\begin{array}{l}\text { Pakistani or } \\
\text { Bangladeshi origin, } \\
\text { men and women of } \\
\text { Muslim heritage } \\
\text { living in East London } \\
\text { and Bardford } \\
\text { (significant Muslim } \\
\text { population, } \\
\text { contrasting } \\
\text { deprivation and } \\
\text { cultural integration } \\
\text { with wider society) }\end{array}$ & $\begin{array}{l}\text { Questionnaire } \\
\text { Measuring } \\
\text { Sympathies for } \\
\text { Violent Radicalisation } \\
\text { and Terrorism } \\
\text { (SyfoR). } 16 \text { items, } \\
\text { Likert scale with } \\
\text { scores of }-3 \text { to }+3\end{array}$ & $\begin{array}{l}\text { Sympathy for violent } \\
\text { protest and terrorism } \\
\text { is associated with } \\
\text { depression. } \\
\text { Resistance to } \\
\text { radicalisation was } \\
\text { associated with larger } \\
\text { number of social } \\
\text { contacts, less social } \\
\text { capital, unavailability } \\
\text { for work due to } \\
\text { housekeeping or } \\
\text { disability and not } \\
\text { being born in the UK. }\end{array}$ \\
\hline $\begin{array}{l}\text { Moyano } 2014 \\
\text { [14] }\end{array}$ & $\begin{array}{l}\text { Assessing the } \\
\text { intended level of } \\
\text { religious } \\
\text { and political activism } \\
\text { and radicalism in a } \\
\text { sample of Muslim } \\
\text { and Christian } \\
\text { youths living in a } \\
\text { marginalized } \\
\text { neighbourhood of a } \\
\text { city in southern } \\
\text { Spain. }\end{array}$ & 115 & $13-17$ & $\begin{array}{l}\text { M } \\
(54 \%) \\
\text { and F } \\
(46 \%)\end{array}$ & Spa & $\begin{array}{l}\text { High levels of } \\
\text { religious } \\
\text { and political } \\
\text { activism and } \\
\text { radicalism }\end{array}$ & $\begin{array}{l}\text { Muslim and Christian } \\
\text { students attending } \\
\text { secondary school in a } \\
\text { marginalized } \\
\text { neighbourhood in a } \\
\text { southern city in Spain }\end{array}$ & $\begin{array}{l}\text { The Activism and } \\
\text { Radicalism Intention } \\
\text { Scales (Moskalenko \& } \\
\text { McCauley, 2009). } 2 \\
\text { Scales: Activism and } \\
\text { Radicalism, } \\
\text { composed of } 4 \text { items } \\
\text { each, Likert scale } \\
\text { with scores of } 1 \text { to } 7\end{array}$ & $\begin{array}{l}\text { Differences in } \\
\text { religious and national } \\
\text { identification were } \\
\text { found between } \\
\text { Muslims and } \\
\text { Christians. Muslims } \\
\text { scored higher in a } \\
\text { statistically } \\
\text { significant way on } \\
\text { various indicators of } \\
\text { religious extremism. } \\
\text { Both perceived } \\
\text { oppression and } \\
\text { shared ideology } \\
\text { inside the endogroup } \\
\text { seem to be } \\
\text { contributing factors } \\
\text { to having an intention } \\
\text { of radicalism in the } \\
\text { Muslim group where }\end{array}$ \\
\hline
\end{tabular}


Table 1 (Continued)

\begin{tabular}{|c|c|c|c|c|c|c|c|}
\hline Author (year) & Study Design & $\mathrm{N}$ & Age & Gender & Country* & $\begin{array}{l}\text { Radicalism } \\
\text { criteria }\end{array}$ & $\begin{array}{l}\text { Features of the } \\
\text { sample }\end{array}$ \\
\hline Coid 2016 [51] & $\begin{array}{l}\text { Cross-sectional study } \\
\text { that investigates the } \\
\text { population } \\
\text { distribution of } \\
\text { extremist views } \\
\text { among UK men }\end{array}$ & 3679 & $18-34$ & $\begin{array}{l}\text { M } \\
(100 \%)\end{array}$ & UK & $\begin{array}{l}\text { Extremism } \\
\text { criteria ("Pro- } \\
\text { British" or } \\
\text { "Anti-British" } \\
\text { positions) }\end{array}$ & General population \\
\hline $\begin{array}{l}\text { Dhami \& } \\
\text { Murray } \\
2016 \text { [35] }\end{array}$ & $\begin{array}{l}\text { Qualitative and } \\
\text { exploratory analysis } \\
\text { of perceptions of the } \\
\text { benefits and } \\
\text { drawbacks of } \\
\text { accessing a violent } \\
\text { extremist website, } \\
\text { joining a violent } \\
\text { extremist group, and } \\
\text { leaving such a group. }\end{array}$ & 57 & $\begin{array}{l}\text { Mean: } 22 \\
\text { years } \\
(\mathrm{SD}=2.9)\end{array}$ & $\begin{array}{l}\text { M } \\
(100 \%)\end{array}$ & UK & $\begin{array}{l}\text { Perceptions of } \\
\text { the benefits of } \\
\text { accessing a } \\
\text { violent } \\
\text { extremist } \\
\text { website, joining } \\
\text { a violent } \\
\text { extremist group } \\
\text { and leaving such } \\
\text { a group }\end{array}$ & $\begin{array}{l}\text { Young men recruited } \\
\text { via universities } \\
\text { within the UK }\end{array}$ \\
\hline
\end{tabular}

Assessment Tools

Assessment Tools

Self-administered survey online asking to imagine the benefits and drawbacks of joining a violent extremist group investigating support for Britain and the war in "Yes", “No" or “don't know" social identity anchored in religion prevails. Men at risk of depression may extremist attitudes, experience protection from strong cultural or

3 responses possible: Antisocial behaviour

increases with extremism;

Religion is protective but may determine targets of violence

following

radicalisation.

Perceived benefits of extremist engagement: gaining knowledge/ awareness, being part of a group/similar people, and fighting the enemy/for a cause.

Drawbacks of extremist engagement: being exposed to negative material and emotions, having violent/criminal beliefs and behaviours, and getting in trouble with the law

Doosje et al. Focus on the process 131 Mean: M $\quad$ Net $\quad$ Evaluation of a 131 young Islamic Online questionnaire by three main factors: 2013 [39] of radicalisation with 17.3 years $(61 \%)$ $(\mathrm{SD}=2.2) \quad$ and $\mathrm{F}$ [12-21] (39\%) Radical Belief System measuring 12 the hypothesis that this process is driven personal uncertainty, perceived injustice, and perceived group threat people. Most of the (95.5\%) were high Predictors and school students. All of Dependent Variables them categorized implicated in a Radicalisation process. 87 items, Likert scale with scores of 1 to 5 . nal uncertainty, perceived injustice, and group-threat

actors are importan determinants of a radical belief system. This radical belief system in turn predicts attitudes toward violence by other Muslims, which is a determinant of own violent intentions

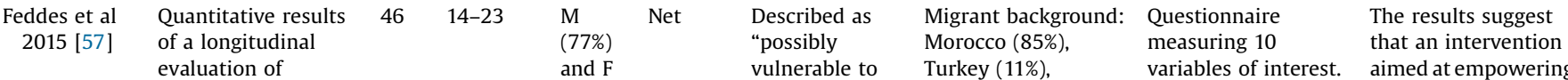

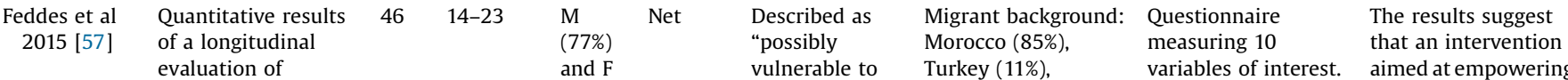
evaluation of resilience training as $\quad(23 \%)$ a possible method to radicalisation" Surinam (1\%), by a community Pakistan (1\%). center or a high prevent violent radicalisation (Diamant; SIPI, 2010) school
Studies focusing on theoretical aspects based on single case reports or small series

Benslama Theoretical proposals NA NA NA Fra NA

2016 [29] based on

psychological care

and clinical

observations of

radicalised patients

and their knowledge

about Islamic

fundamentalisms
NA NA

A


Table 1 (Continued)

\begin{tabular}{|c|c|c|c|c|c|c|c|c|c|}
\hline Author (year) & Study Design & $\mathrm{N}$ & Age & Gender & Country* & $\begin{array}{l}\text { Radicalism } \\
\text { criteria }\end{array}$ & $\begin{array}{l}\text { Features of the } \\
\text { sample }\end{array}$ & Assessment Tools & Main Findings \\
\hline $\begin{array}{l}\text { Dayan } 2015 \\
\text { [43] }\end{array}$ & $\begin{array}{l}\text { Theoretical } \\
\text { conclusions based on } \\
\text { psychological } \\
\text { observations of } \\
\text { recent French } \\
\text { terrorists and the } \\
\text { radicalisation } \\
\text { phenomenon in } \\
\text { French society }\end{array}$ & NA & NA & NA & Fra & NA & NA & $\begin{array}{l}\text { Psycho-analytic } \\
\text { method }\end{array}$ & $\begin{array}{l}\text { the importance of the } \\
\text { radicalisation } \\
\text { phenomenon } \\
\text { Description of the } \\
\text { dehumanisation } \\
\text { process and the } \\
\text { importance of the } \\
\text { group and the } \\
\text { collective psychology. }\end{array}$ \\
\hline $\begin{array}{l}\text { Khosrokhavar } \\
2014 \text { [4] }\end{array}$ & $\begin{array}{l}\text { Theoretical } \\
\text { considerations and } \\
\text { observations about } \\
\text { the radicalisation } \\
\text { phenomenon using a } \\
\text { sociological point of } \\
\text { view }\end{array}$ & NA & NA & NA & EU & NA & $\begin{array}{l}\text { Worked mostly with } \\
\text { radicalised } \\
\text { individuals in prison }\end{array}$ & Sociologic approach & $\begin{array}{l}\text { Description of a new } \\
\text { European model of } \\
\text { "introverted" } \\
\text { radicalisation: } \\
\text { smaller groups, less } \\
\text { proselytic (more } \\
\text { concealment) and } \\
\text { more psychological } \\
\text { fragility among its } \\
\text { members. }\end{array}$ \\
\hline $\begin{array}{l}\text { Khosrokhavar } \\
2015 \text { [37] }\end{array}$ & $\begin{array}{l}\text { Theoretical } \\
\text { considerations and } \\
\text { observations about } \\
\text { the radicalisation } \\
\text { phenomenon using a } \\
\text { sociological point of } \\
\text { view }\end{array}$ & NA & NA & NA & EU & NA & $\begin{array}{l}\text { Worked mostly with } \\
\text { radicalised } \\
\text { individuals in prison }\end{array}$ & Sociologic approach & $\begin{array}{l}\text { Distinction in the } \\
\text { process of } \\
\text { radicalisation } \\
\text { between European } \\
\text { radicalised } \\
\text { individuals from the } \\
\text { middle classes, } \\
\text { European radicalised } \\
\text { individuals with } \\
\text { ghettoized living } \\
\text { conditions and } \\
\text { European radicalised } \\
\text { girls. }\end{array}$ \\
\hline $\begin{array}{l}\text { Leuzinger- } \\
\text { Bohleber } \\
2016 \text { [36] }\end{array}$ & Single case & 1 & 28 & M & Ger & $\begin{array}{l}\text { Joined a violent, } \\
\text { radical right- } \\
\text { wing youth } \\
\text { group }\end{array}$ & $\begin{array}{l}\text { After humiliation by a } \\
\text { teacher, he lost } \\
\text { interest in school and } \\
\text { joined the radical } \\
\text { group }\end{array}$ & $\begin{array}{l}\text { Psycho-analytic } \\
\text { method }\end{array}$ & $\begin{array}{l}\text { Importance of } \\
\text { adolescent issues in } \\
\text { the process of } \\
\text { radicalisation. } \\
\text { Need to sensitize } \\
\text { professionals who } \\
\text { take care of } \\
\text { adolescents so that } \\
\text { they can accompany } \\
\text { them in their search } \\
\text { for belonging }\end{array}$ \\
\hline $\begin{array}{l}\text { Ludot et al. } \\
\qquad 2016 \text { [32] }\end{array}$ & Single case & 2 & $14-15$ & $\begin{array}{l}\text { M } \\
(50 \%) \\
\text { and F } \\
(50 \%)\end{array}$ & Fra & $\begin{array}{l}\text { Conversion to } \\
\text { Islam and } \\
\text { subsequent } \\
\text { reality } \\
\text { confirming the } \\
\text { process of } \\
\text { radicalisation }\end{array}$ & $\begin{array}{l}\text { Adolescents with } \\
\text { previous difficulties } \\
\text { more "common" at } \\
\text { their age and family } \\
\text { dysfunction }\end{array}$ & $\begin{array}{l}\text { Clinical material from } \\
\text { psychiatry sessions }\end{array}$ & $\begin{array}{l}\text { Importance of } \\
\text { grasping the way } \\
\text { each teenager } \\
\text { considers the } \\
\text { phenomenon of } \\
\text { radicalisation. } \\
\text { Individual issues that } \\
\text { are found relate to } \\
\text { more-common } \\
\text { problems also found } \\
\text { in conventional } \\
\text { teenage care. }\end{array}$ \\
\hline
\end{tabular}

EU: European Union; Fra: France; Ger: Germany; Ned: Netherlands; Spa: Spain; UK: United Kingdom; IS: Islamic State.

the power of jihadist attraction comes from the 'exalting promise' that offers the adolescent a 'soothing of the pain of living' [29]. Several authors hypothesise that radical ideology could often hide a suicidal intentionality. The notion of martyrdom is attractive because it gives meaning to one's existing fragilities and suicidality. The issue of suicidal intentionality remains complex. While some authors insist that the promise of a 'true' life in the hereafter gives to death a saving status $[4,29]$, others evoke preexisting suicidal intentionality for certain subjects [30]. The relationship to death probably varies from one subject to another and is somehow reflected in the radical ideology that gives death a central place. This echoes Durkheim's notion of 'altruistic suicide' by excess of integration [31]. In total, we lack empirical evidence to address the issue of suicidal intentionality among radicalised youths.

A history of addictive behaviour is often reported. Dependence on the radical group may act as a substitute product and replace the previous addiction: some subjects reported that the positive and rewarding effect of religious commitment allowed them to get rid of an addiction to a substance [7,32]. Radical commitment can also be conceptualised as a risky behaviour, with all the appeal it has for teenagers. For radicalised youths, going to Syria represents an initiatory quest [4,33]. Addictive behaviour, risky behaviour and sensation seeking attitudes are common conduct disorders found 
Table 2

Existing categorizations and typologies for radicalised youth.

\begin{tabular}{|c|c|c|}
\hline Author (year) & Studied Population & Proposed Categorization/Typology \\
\hline $\begin{array}{l}\text { Bazex \& } \\
\quad \text { Mensat } \\
2016[33]\end{array}$ & $\begin{array}{l}\text { Judicial expertise of } 12 \text { individuals who went to Syria to join ISIS } \\
\text { and came back. } \\
\text { Age: } 21-27 \text {, Only Men. }\end{array}$ & $\begin{array}{l}\text { 3 Profiles: } \\
\text { 1. Ambitious Delinquent } \\
\text { 2. Converted Preacher } \\
\text { 3. Criminal belonging to a network }\end{array}$ \\
\hline $\begin{array}{l}\text { Bazex \& } \\
\text { Bénézech } \\
2017 \text { [27] }\end{array}$ & $\begin{array}{l}112 \text { Individuals perceived as radicalised by the penitentiary crew. } \\
\text { Age: } \text { mean }=30,96 \% \text { men }\end{array}$ & $\begin{array}{l}\text { 4 Profiles: } \\
\text { 1. Ambitious Delinquent } \\
\text { 2. Criminal Proselyte belonging to a network } \\
\text { 3. Person in situation of precariousness } \\
\text { 4. Serious mental illness }\end{array}$ \\
\hline $\begin{array}{l}\text { Bouzar } 2016 \\
\quad[30]\end{array}$ & $\begin{array}{l}809 \text { young people whose family has reported Muslim } \\
\text { radicalisation and tried to join the IS. } \\
\text { Age: } 12-30 \text {. Majority girls (60\%) }\end{array}$ & $\begin{array}{l}\text { 8 Motives for commitment: } \\
\text { 1. Lancelot } \\
\text { 2. Zeus } \\
\text { 3. Saviour } \\
\text { 4. Daeshland } \\
\text { 5. "Mother Teresa" } \\
\text { 6. The Sleeping Beauty } \\
\text { 7. Fortress } \\
\text { 8. Para-suicidal }\end{array}$ \\
\hline $\begin{array}{c}\text { Khosrokhavar } \\
2015 \text { [37] }\end{array}$ & $\begin{array}{l}\text { Theoretical considerations and observations about the } \\
\text { radicalisation phenomenon on an unspecified sample of } \\
\text { European people }\end{array}$ & $\begin{array}{l}\text { 1. Disaffiliated youth living in marginal social conditions } \\
\text { 2. Youth from the middle class } \\
\text { 3. Young girls }\end{array}$ \\
\hline $\begin{array}{l}\text { Ludot et al. } \\
\qquad 2016[32]\end{array}$ & $\begin{array}{l}2 \text { case reports of radicalised adolescents who do not come from a } \\
\text { Muslim family. } \\
\text { The Male adolescent is } 14 \text { years old and the Female adolescent is } \\
15 .\end{array}$ & $\begin{array}{l}\text { 2 Profiles: } \\
\text { 1. Young Muslim who hates society (importance of the geopolitical and the social } \\
\text { context) } \\
\text { 2. Young middle-class convert who breaks with his original filiation (less importance } \\
\text { of the geopolitical and the social context) }\end{array}$ \\
\hline
\end{tabular}

among delinquent adolescents [34]. Radical commitment channels these behaviours by giving to the subject a firm framework within the group. Finally, early experiences of abandonment are found in most of the radicalised youth's life trajectories [33]. A perceived fragile family structure and painful parental representations are vulnerability factors for youth radicalisation [28,33].

Adolescence per se is a risk factor for radicalisation. Adolescence is a phase of turbulence and reorganisation. For some adolescents, the inherent detachment from primary care givers and finding one's own identity bring a loss of security and sometimes a fear of loneliness and of being abandoned [28,32]. Belonging to a radical community conveys a sense of belonging, a sense of meaning and comfort [35]. Based on the psychoanalysis of a radicalised subject and the content of jihadist propaganda, Leuzinger-Bohleber claims that the IS permits the satisfaction of pre-genital drives, which are rekindled in the early phases of adolescence [36]. Violent actions advocated by radical groups unconsciously offer an enormous satisfaction of archaic drive-impulses and can be experienced as an omnipotent victory over the fear of death [36]. Also, finding love objects outside of the family is another major issue of adolescence and is simplified by the organisation, which guarantees a reassuring marriage [36]. Motivation towards marriage is found more frequently in young girls than in young men who are generally more attracted by the fascination exerted on them by armed combat $[30,37]$. The changes in identifications during adolescence and the quest for an ideal open the way to radical ideologies [32]. Thus, the message sent by the IS may become attractive for some adolescents. The adolescent characteristics of the radicalisation process had not been put forward in the terrorist movements of the 1990s and 2000s. Bazex and Bénézech showed an age effect on the reason of justice control: subjects under judicial control for acts of apology or for acts of terrorism are much younger than those condemned for ordinary law crimes. On one hand, there are young people for whom radical engagement leads them to be under judicial control, and on the other side there are condemned adults who meet, by availability, radicalisation in prison. Individuals in prison can encounter radical commitment in a very variable way [27].

Personal uncertainty is another individual risk factor for radicalisation. Identity and identification issues and idealisation processes are central during adolescence. For several authors, these issues are at the core of the radicalisation process. The neoidentity associated with the radical group and ideology may give a new and reassuring meaning to the young person's experience [32]. Some add a dimension of imaginary affiliation to fallen Muslim origins that the subject glorifies again through his/her commitment [29]. Radicalisation is viewed as an 'act of recovery of identity' or 'recovery of lost dignity' [37]. Members identify with the leader's power and prestige which compensate for the failures of their individual narcissism [7]. Theories of narcissism and grandiosity in groups highlighted the fact that the figure of the leader and the ideology becomes for the members of the group their ego ideal [38]. This mechanism acts as a megalomaniac protection against anguish that reinforces the subjects' fantasies of immortality [38]. Middle-class youths can also experience this feeling of 'victimisation' by suffering from anonymity and nonbelongingness. The latter could therefore also engage in jihadism because of a lack of identity firmly anchored in reality. The fact that adolescents from middle class and without family affiliation with Islam undergo radicalisation process underlines the importance of 
the adolescence process in this choice of radical engagement [32]. For Doosje, personal uncertainty is one of the three main determinants of a radical belief system, along with perceived injustice and perceived intergroup threat [39]. This finding is based on Hogg's 'uncertainty-identity' theory: the more individuals are uncertain in their environment, the more likely they are to identify themselves massively with groups [40], and the more the properties of this group form a unit where individuals seem interchangeable, the more effectively this group reduces uncertainty [41].

Perceived injustice, or the feeling of injustice, is another determinant of radicalisation. It is cited in several studies, whatever the vocabulary or the methodology used: 'Perceived injustice' [39], 'Perceived Oppression' [14], 'Frustration' [27], 'Despair', 'Sense of Unworthiness' or 'Perceived contempt' [37]. All these terms illustrate a deep malaise of the subject who tries to give sense to this 'existential failure'. This 'injustice' is often put forward by the radicals themselves to justify their commitment and designate the culprits. Benslama also explains that this feeling of injustice, often provoked by personal experience, is then covered by radical ideology, giving a stronger value to its commitment [29]. The link between perceived injustice and the reality of a socioeconomic discrimination is developed below (see macro-envionnemental risk factors).

Several authors state the importance of a triggering event as a determining factor in acting out or at least reinforcing the radical commitment. The list of events includes the occurrence of a brutal trauma concerning a loved one (e.g., bereavement, illness, separation) [30,42]; the occurrence of a love disappointment [33]; the viewing of a video of a battered woman who reminded him of his mother [42]; or the viewing of a video that reactivated a profound suffering linked to family history [33]; and a recent experience of discrimination or the diffusion of violent and unsustainable videos [30].

Finally, several authors have described psychopathological mechanisms that are at stake during radicalisation and that reinforce radical engagement. The idea here is to explain the psychological mechanisms involved once the individual has started the process of radicalisation. First, projection is active: radical ideology offers the subject the possibility to project onto his enemies all the evil he feels inside and to soothe his guilt by what is designated as an act of purification [43]. This operation may be accompanied by a paranoia mechanism and a use of splitting of the ego. This paranoia mechanism acts as a defense mechanism and does not account for a psychiatric pathology or personality organisation $[7,27,29]$. The splitting process is highlighted by several authors and explains how these individuals can set aside the moral values they had in the past $[15,30,43]$. Various authors have reported that obsessive compulsive habits are also frequent among radicalised youth $[29,30]$. These symptoms often have a function of 'purification', such as found in radical ideology or the practice of a rigorist religion. Radical engagement may soothe pre-existing anxiety symptoms by offering a reassuring framework. For Khosrokhavar and Ludot, today's European jihadists of the middle classes suffer from a lack of authority and are in need of an authoritarian normativity that shows them rules to follow [32,37]. These elements show the importance of the radical group that welcomes the candidates to radicalisation, and they suggest how the influence of the micro-environment is decisive in the process of radicalisation.

\subsection{Micro-environmental risk factors (family and proximal environment)}

Fragility and failure of the family group is a risk factor for radicalisation. Studies focusing on the families of radicalised youths often portray deficiencies, traumas and/or distress during the childhood and adolescence of these subjects [4,28,33]. In Bazex and Bénézech's study, which included 112 individuals under judicial control for radicalisation, they report a large proportion of individuals who experienced 'a childhood marked by significant parental difficulties, a father often absent and a mother whose integrity is often attacked (depression, suicide attempt, disability)' [27]. In their view, this contributes to a major inconsistency in identificatory processes (in other words, identity uncertainty). Among the members of the Hofstadgroup, a Dutch terrorist organisation, Schuurman found that one of the risk factors that makes the radical group particularly effective is the isolation of the subject and the absence of countervailing opinions in the family [42]. The lack of a corrective answer to the subject's radical positions was also reported by Van San et al among 16 Islamists and extreme right adolescents who exposed on the internet their radical ideas [44]. He described permissive parents with little response to their child's radical opinions.

Friendship or admiration towards a member of the radical group is often reported. This seems obvious in studies focusing on the mostextremist cases seen in judicial contexts. Most of the radicalised individuals had a role model, an inspirational figure in the radical group who initiated the process of radicalisation. Schuurman highlighted this finding for individuals among the 'Hofstadgroup' in Holland, and Bazex confirmed it among French radicalised youths returning from Syria [33,42].

Several authors have found similarities between the techniques of radical jihadist groups and sectarian community methods to recruit new members. Based on his knowledge of sectarian methods, Dayan described common mechanisms such as narcissistic gratification, moral debt, real or imagined threats and the progressive setting aside of the family/friendship network [43]. Rolling described two phases in the radicalisation process of the youth encountered in child psychiatry units: a first phase during which the radical commitment has a soothing function on psychic suffering and a second phase during which the ideological indoctrination leads to the self-effacement of the subject in favour of the group [28]. Bouzar studied the way the youth was enlisted on the internet and explained that the 'recruiters' of radical groups adapt the propaganda media to the 'sensitivity' of each subject $[30,45]$. Youths are subject to psychological pressure from the recruiters to adopt the radical beliefs and to break with friends and family [46]. Bazex \& Bénézech highlighted one category of radicalised individuals who have a charismatic character associated with proselytic and manipulative behaviours: 'the proselytic networker' [27]. Radicalised individuals with other profiles (e.g., 'ambitious offenders'; 'people in a precarious situation') may be vulnerable to indoctrination by 'proselytic networkers'. Khosrokhavar also reported this form of relational dissymmetry between a charismatic individual who exerts an influence on more-fragile individuals [4].

The radical group instigates the subject's dehumanisation. This is a key process to understanding how mainly normal individuals can engage in terror activities. For Bazex \& Bénézech, the radical group and ideology help to legitimise a pre-existing violence in the subject [27]. The aggressive and destructive instincts that dominate the fantasy life of these individuals find a way of justification and ideal expression in projection towards the outside. Dayan states that there is a 'narcissistic contract' between the individual and the group and that this contract is crucial: the group offers a place and a role to the subject, and in exchange, he must repeat the same statements and ensure the permanence of this transmission [43]. Khosrokhavar studied the case of young Europeans who wanted to go to Syria [4]. He explained that this desire was more often driven by humanitarian concerns than by violent radicalism. He described these young people as 'pre-radicalised' and explained that once 
within the group, they learn to become insensitive to the suffering of others and becoming 'real jihadists'. Bouzar identifies four steps used by recruiters in order to effect the 'dehumanisation' of the subjects: (i) isolation of the individual from his environment; (ii) destruction of the individual as a unique personality for the benefit of the group; (iii) adherence to the IS ideology; (iv) dehumanisation of the subject and of his future victims [46]. These steps are consistent with Bandura's work on 'moral agency' and dehumanisation: 'The moral disengagement may center on the cognitive restructuring of inhumane conduct into a benign or worthy one by moral justification, sanitising language, and advantageous comparison; disavowal of a sense of personal agency by diffusion or displacement of responsibility; disregarding or minimising the injurious effects of one's actions; and attribution of blame to, and dehumanisation of, those who are victimised' [47]. These mechanisms are also described by Zagury [15] and Bouzar [46] when they explore the link between the 'recruiters' and the youth exposed to radical theories.

\subsection{Macro-environmental risk factors (cultural and societal environment)}

The evidence of macro-environmental factors is more complex. Social polarisation is one such risk factor. Unequal or discriminatory socio-economic conditions are highlighted by many authors as contributing to the phenomenon of radicalisation. Khosrokhavar explains that the 'ghettoized existences' associated with the sense of dehumanisation subjects feel through social disregard lead them to the desperate conviction of being in a deadlock [4]. When this conviction is not associated with an ideology, these young people may take the path of delinquency. If this conviction finds religious ideological support, the hatred of society is sacralised and the goal becomes to 'save Islam'. Khosrokhavar noted that most French people who have committed terrorist acts were born in disorganised families, had grievances against society, had a feeling of social injustice and a denial of identity (feeling neither French nor from their country of origin) [4]. Moyano studied Muslim and Christian high school students in Spain and showed a significant polarisation between the two groups when they came from the same neighbourhood [14]. When asked what defines them best, Muslims mostly chose identification with religion (when they could choose Spain or their country of origin), while Christians chose their country. Similarly, French authors reported that young people who have returned from Syria or young people under the grip of justice for radicalisation often had difficulties in social integration, particularly at school, with a history of exclusion [27,33].

Doosje et al identified perceived group threat as a major contributor to maintaining a radical belief system [39]. The perceived group threat may take three different forms: symbolic threat, realistic threat, and intergroup anxiety. Symbolic threat refers to threat to the Islamic culture. Realistic threat refers to threat to the economic status of one's group. Intergroup anxiety is defined as the fear one can experience when one has to interact with a person from another group. Once again, these results underline the importance of group polarisation and its consequences for feelings of oppression or perceived injustice. Bhui supports the use of a public health approach to understand and prevent violent radicalisation, arguing that anti-terrorism approaches based on the judicial system or on criminology do not prevent radicalisation, since they intervene after the act [48]. These latter actions would even tend to stigmatise Muslim communities and undermine social cohesion, while better social cohesion is associated with a reduction of violence, better public health, and a more equal and just society. To support this view, Bhui et al. studied vulnerability factors and resistance factors to violent radicalisation in a cross-sectional survey of a representative population sample of men and women aged 18-45 of Muslim heritage in two English cities [49,50]. They showed that sympathy for violent protest and terrorist acts was more likely to be articulated by those under 20 , by those in full time education rather than employment, by those born in the UK, by those speaking English at home, and by high earners ( $>£ 75,000$ a year). Anxiety and depressive symptoms, adverse life events and sociopolitical attitudes showed no associations. On the other hand, resistance to radicalisation measured by condemnation of violent protest and terrorism was associated with a larger number of social contacts, less social capital, unavailability for work due to housekeeping or disability, and not being born in the UK [49,50]. Interestingly, here again, sympathy was higher among the youngest individuals and those born in the UK rather than immigrants $[49,50]$. In another cross-sectional study in the UK, Coid et al showed that men at risk of depression may experience protection from strong cultural or religious identity [51]. These results seem paradoxical and highlight the importance of a consideration at all three levels (macro, micro and individual): some factors can act either on the side of protection or of vulnerability to a radical system.

The link between religious fundamentalism and radicalisation is complex. Many authors mention the importance of religion in the process of radicalisation. Moyano reported that Muslim religious identity was stronger than Christian identity in Spain [14]. Dayan noted recent claims of religious identity among French youths [43]. Coid showed that religious affiliation and practice were protective against antisocial behaviours but could determine targets of violence following radicalisation [51]. Benslama emphasised the importance of the history of the Arab world and Islam in explaining the discourses of Islamic fundamentalists and the creation of a new identity figure that he called the 'superMuslim' [29]. According to Benslama, there is a 'constraint under which a Muslim is led to outbid the Muslim he is by the representation of a Muslim who must be even more Muslim'. The subject is encouraged to identify himself with 'the perfect Muslim, the Prophet and the ancestor', according to the belief that 'the good has already happened, the promise has been fulfilled, there is nothing left to do but to return to the past, while waiting for the end of the world, or better: to hasten it' [29]. Benslama illustrates how religious fundamentalism provides an identity figure in which youths can find a totalising meaning. It is crucial to differentiate Muslim religion from radical Islamist ideology. Some political scientists have argued that for ISIS, religion is more a way to justify their actions, rather than a cause to defend, unlike other forms of religious fundamentalism [52].

The geopolitical context also has a major influence. Several authors have noted that the proclamation of a caliphate by the IS added legitimacy to this radical ideology $[4,29,30]$. Contrary to the Al-Qaeda network, the IS is anchored in a territory, and its propaganda describes the territory as an idyllic place, a community utopia where the Muslim 'brothers' are most welcome. Different terms have emerged, conveying the message of ideological propaganda associated with this territory: the 'Hijra' (emigration of a Muslim from a non-Muslim country to a Muslim country), the 'Land of Al-Sham' (literally 'land on the left-hand', referring to a Caliphate province in the region of Syria) or 'Ummah' (world community of Muslims). Geopolitical events undoubtedly influence the phenomenon of radicalisation whether in its rise in 2014 during the proclamation of the caliphate or during its decrease in intensity since the IS was defeated in Syria and Iraq in 2017.

Societal changes may affect the radicalisation process. According to various authors, the mutations of modern societies may favour the appearance of the phenomenon of radicalisation. 
Khosrokhavar uses Durkheim's term 'Anomie' [53] to explain that thedissolution of the moral, religious or civic values of modern societies leads to a feeling of irresolution that makes youths more inclined to turn towards religious fundamentalisms and possibly towards radical ideologies [4]. These considerations are in line with Zygmunt Bauman's more modern concept of 'liquid modernity', according to which the individual is integrated only by his act of consumption [54]. Social status, identity or success are defined in terms of individual choices and can fluctuate rapidly depending on socio-economic requirements. This fluid modernity brings at the same time freedom but also uncertainty and insecurity. Khosrokhavar [37] adds that among these young people, who suffer from the 'deliquescence of politics' and the 'dispersion of authority between several parental bodies', radical Islamism offers tangible and reassuring norms carried by an unequivocal authority. Benslama also discusses this change in the social model [29]. He explains that the traditional model, in which filiation defines the identity of the subject, is endangered in favour of a new social model where each subject needs to forge his own place and identity, with all the anxiety it can generate. Some individuals have the resources to face this challenge, but those who fail to do so may be tempted by the solutions offered by the radical ideologies by attacking the society that has placed them in this insecure situation. Radicalised individuals believe that radical ideology, by destroying the existing society, offers them the possibility of a promising new societal model. Also, the society is believed to convey all kinds of conspiracies by forces that stole power from the people (e.g., financial power), and IS recruiters use conspiracy theories to destroy the world of candidates to radicalisation to make them commit to a new one $[30,45]$.

\section{Discussion}

4.1. Three-level model for the radicalisation process among European youths

In an attempt to summarise the main results of this review, we have developed a three-level model to explain the phenomenon of radicalisation among young Europeans since 2010. This model is shown in Fig. 2, and it follows the proposal of Doosje et al. [55]. However, it also includes some differences and the idea that some factors should be regarded as interactive factors between an individual who commits to radicalisation and a recruiter who tries to favour this process. As in Doosje et al.'s model, we distinguish individual, micro-environmental and macro-environmental factors (which are named micro-, meso- and macro-levels, respectively, in Doosje). We preferred to use the usual distinction employed in child and adolescent epidemiology of at-risk behaviour [56]. The red circle encompasses the different factors that show the interaction between the subject and the radical system whatever the level: mechanisms at stake during the process of radicalisation at the individual level, similarities with the sectarian communities and the use of dehumanisation to justify the use of violence at the micro-environment level, and the proposal of a new societal model at the macroenvironmental level.

\subsection{Is it possible to formulate recommendations?}

The multifactorial aspect of the radicalisation process implies that the proposals imagined to prevent this phenomenon are varied. Using the three levels previously described, we synthesised the different recommendations that have been formulated inside and outside the literature review in order to prevent radicalisation. We also emphasised the proposals that have been discussed through empirical data.

At the individual level, we only find two empirical studies describing a de-radicalisation program. The first study used an anthropological perspective with a large number of French individuals [30]. They proposed a combination of socio-educative support, therapeutic groups of de-radicalisation to help individuals experiencing novel emotional associations with previous life trajectory, and family therapy [46]. No outcome data are available to date. The second study was based on a Dutch radicalisation prevention program, the DIAMANT program [57]. The training consists of three modules ('Turning Point', 'Intercultural Moral Judgment' and 'Intercultural Conflict Management') conducted

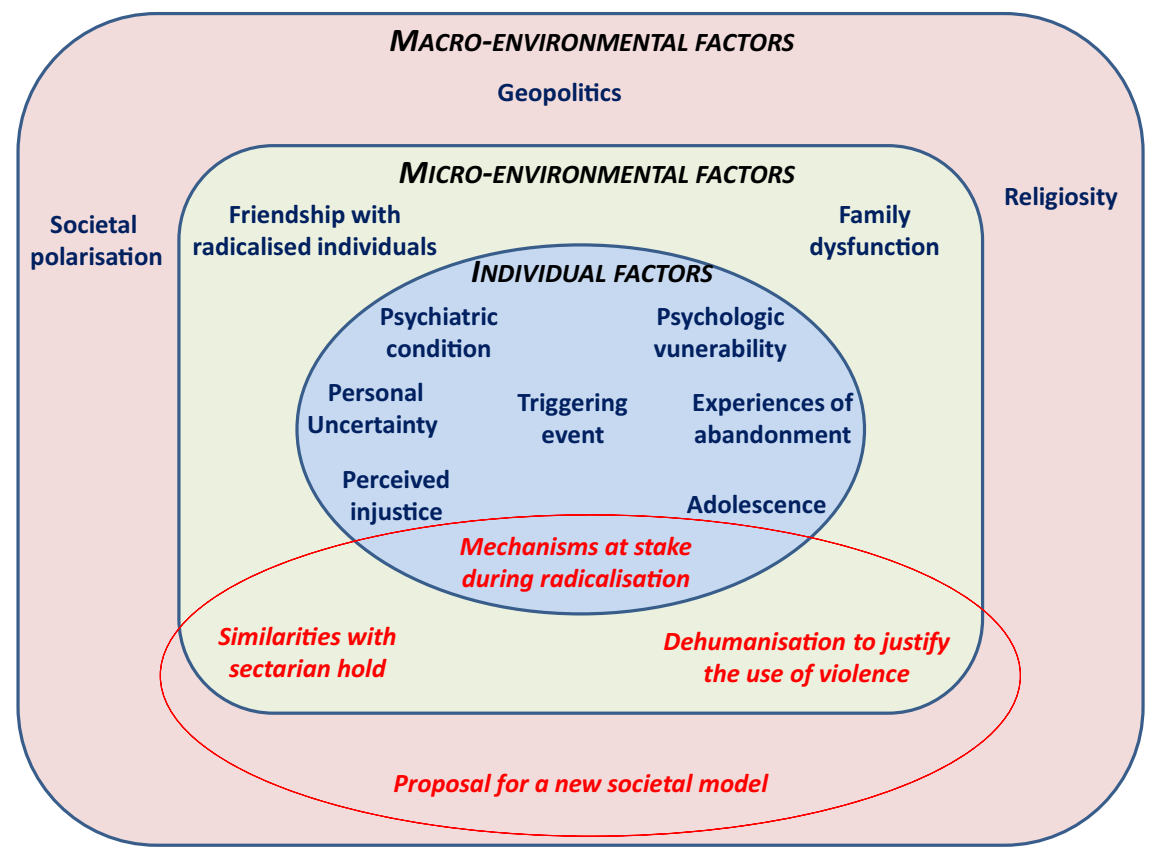

Fig. 2. Risk factors of radicalisation among European youth: a three-level model. 
over a period of 3 months. The first goal of DIAMANT is to help participants find a job, internship, or education in order to reduce feelings of relative deprivation and social disconnectedness. Regarding prevention, Feddes et al. reported a longitudinal study showing that improving empathy and agency skills, as well as balancing self-esteem (neither too strong nor too weak), could prevent the risk of violent radicalisation [57]. Based on case reports and series, Ludot et al reported the importance of mental health professionals meeting these young people (i) to analyse their psychological vulnerability, taking into account their political, social and cultural context, and (ii) to try to grasp the meaning radical commitment holds for them [32]. Zagury insisted that it is important for mental health professionals to offer young people psychological support without judgment [15]. The lack of judgment from professionals is a necessary condition for deradicalisation. Bazex \& Bénézech point out that for mental health professionals in prison, it is crucial to search for dissimulation strategies, because they hinder psychotherapeutic work [27].

At the micro-environment level, Van San et al. underlined the benefits of a pedagogical approach, in which a benevolent educator accompanies a young person by setting limits for him while offering him a discourse that counterbalances extremist ideologies, an approach that could prove to be relevant for prevention [44]. Khosrokhavar proposed the formation of groups of imams, city officials, police officers, neighbourhood authorities and psychologists in order to show to youth accustomed to violence that a constructive dialogue exists among these people [4]. According to him, repression will never be enough to combat these violent ideologies, so a preventive approach is essential. Leuzinger-Bohleber reported the case of a radicalised young man who identified a determining event in his distress: a teacher he appreciated and identified as a father figure humiliated him in class [36]. Although the case per se illustrates a triggering event, she proposed setting up supervision groups for teachers, educators and social workers to raise their awareness of transference phenomena. This supervision would strengthen the ability of these professionals to offer the youth a sense of belonging and anchoring in another group than the radical group. We believe that supervision and formation should not be limited to transference phenomena but should also include social exclusion phenomena of all kinds, including first signs of radicalisation [58] and in-group out-group perspectives [59].

At the macro-environmental level, Bhui et al. showed that there are modifiable risk and protective factors for the earliest stages of the radicalisation process [49,50]. They proposed a global approach centred on social inclusion/exclusion, cultural identity, acculturation, stigmatisation and political commitment [48]. The fight against the emergence of radicalisation also involves the prevention of major depressive symptoms and the promotion of well-being and social capital. The fight against these societal risk factors would, in any case, be beneficial on a large scale, since these risk factors are also those of violence and poor health in general. Moyano explained that the polarisation between Christian and Muslim groups is certainly the 'antechamber' of radical commitment [14]. Thus, he insisted on the need to pursue a policy that fights against these in-group polarisations reinforced by sociocultural inequalities. Leuzinger-Bohleber emphasised the importance of defending freedom of expression and open dialogue around societal issues such as migration, trauma or sexuality in order to offset simplistic radical ideology [36]. Khosrokhavar wondered whether non-violent Islamist fundamentalism (Salafism) could be a protective factor against radical violence [4]. For him, it is important to fight against the amalgam and to mark the difference between religious fundamentalism and radical violent jihadist movements.

\subsection{Implications for adolescent psychiatry}

The literature review points out that radicalisation cannot be directly linked to mental illness. Individuals with psychosis are the exception rather than the rule. The resulting psychiatric treatment are suitable only for a minority of situations and there is no specific profile leading to radicalisation. However, the multiple psychological vulnerabilities as well as their similarities with the psychopathological mechanisms of adolescents with mental and behavioural difficulties (e.g. suicidality; conduct disorder; addiction) suggest a key role for adolescent psychiatry in terms of secondary and tertiary prevention. The recent report published by the French Psychiatric Federation on the link between radicalisation and psychiatry thoroughly supports the role of psychiatry [60]. The authors explain: (a) there is 'an encounter between a banal process of painful adolescence and the power of the religious who, by abolishing doubt, meets the conditions of an efficient narcissistic repair'; and (b) 'there is no specific psychopathology, but there is a specific form of expression of a common psychopathology' of the adolescent period. As a consequence, mental health professionals can intervene in two ways to face radicalisation $[28,32,60]$. First, they have a role to play in helping adolescents or young adults to find the meaning the radical commitment has for themselves. Psychotherapeutic intervention (in individual or in group) can enable the young person to understand his personal functioning, to adopt a different point of view, beyond the political, cultural or judiciary approaches, and to find other paths than radicalisation. The links between radicalisation and adolescence psychopathology invite to consider this phenomenon from the eyes of psychiatrists or psychologists familiar with adolescence issues. Second, mental health professionals could be involved in deradicalisation programs in order to drag subjects out of their radical engagement. Knowing the specificities of adolescents and young adults in psychological treatment, they can propose adapted therapeutic devices which are 'likely to rehumanise the functioning of the subject by reducing the factors which induced its narcissistic regression and its reaffiliation in the process of radicalisation' [60]. We believe that this dynamic apprehension of the adolescent mind offers a way out of the radical commitment for a number of young subjects, whose dehumanisation and dilution within the radical group is not yet too advanced.

\subsection{Study limitations and future research}

Radicalisation and terrorism are major issues in our society. This article is the first multidisciplinary systematic literature review focusing on the radicalisation of young people in Europe since 2010. It tried to encompass both qualitative and quantitative studies. There is no decisive explanatory factor for radicalisation but rather a multitude of vulnerability factors that are difficult to handle in a prevention perspective. We developed a comprehensive three-level model of the radicalisation process. We believe that this broad three-level vision can be useful in understanding and apprehending the complexity of the phenomenon. Although this openness is necessarily weakening in terms of theoretical consistence of our subject, it seemed necessary to offer a holistic model in order to bring together the different fields working together on such an important subject. Besides, the fact that there is no explanatory factor is certainly explained by the epiphenomenal aspect of radicalisation whose sudden appearance is part of a complex entanglement of contextual factors. One of the specificities of adolescent psychopathology is to manifest itself in the social field [61].

However, this literature review has several biases due to the complexity of the phenomenon and the variety of youth 
characteristics. First, there are few empirical studies on the subject, and the inclusion criteria of the populations are highly variable (see Table 1). Most studies are qualitative studies, with a small number of subjects. This raises questions about the representativeness of some studies or the generalisation of some results outside the specific context in which the studies were performed. Second, many studies focused on subjects who had committed violent actions and who had a judicial history, which is not representative of today's radicalised population. Third, the majority of the subjects included in the studies are men (with the notable exception of $[28,30])$, while it is known that the number of young radicalised women is significant. Further research is needed to broaden the scope of subjects to radicalised young women and to radicalised subjects who never committed violent actions. Finally, although our aim was to focus on young individuals, many studies selected also included adults older than 25 years questioning the generalisation of the results.

It is also fundamental to develop more empirical research using multidisciplinary approaches to the phenomenon. Different scales have been developed in order to assess sympathy for radical movements in the general population (Syfor [49], RIS [62], and Doosje's scale [39]), but none of them has been validated. It would be useful if field professionals who have met radicalised youths were to develop an evaluation grid specifically designed for individuals perceived as at risk by the healthcare, judicial and penitentiary institutions. It is crucial to develop specific tools to study the phenomenon and to evaluate programs aimed at preventing radicalisation in order to combat this phenomenon that threatens our society.

\section{References}

[1] Horton R.. Offline: a physician's response to religious conflict. Lancet 2016;388:448, doi:http://dx.doi.org/10.1016/S0140-6736(16)31149-7.

[2] Reardon S. Terrorism: science seeks roots of terror. Nature 2015;517:420-1, doi:http://dx.doi.org/10.1038/517420a.

[3] Wieviorka Michel. Sociétés et terrorisme. Paris: Fayard; 1988.

[4] Khosrokhavar Farhad. Radicalisation. Paris: Éditions de la Maison des sciences de l'homme; 2014.

[5] Sageman M. Understanding terror networks. Philadelphia, PA: University of Pennsylvania Press; 2004.

[6] Fekih-Romdhane F, Chennoufi L, Cheour M. Les terroristes suicidaires: qui sont-ils? Ann Méd-Psychol Rev Psychiatr 2016;174:274-9.

[7] Bénézech M, Estano N. À la recherche d'une âme: psychopathologie de la radicalisation et du terrorisme. Ann Méd-Psychol Rev Psychiatr 2016;174:235-49.

[8] McGilloway A, Ghosh P, Bhui K. A systematic review of pathways to and processes associated with radicalization and extremism amongst Muslims in Western societies. Int Rev Psychiatry 2015;27:39-50, doi:http://dx.doi.org/ 10.3109/09540261.2014.992008.

[9] McCauley C, Leuprecht C, Hataley T, Winn C, Biswas B. Tracking the war of ideas: a poll of Ottawa Muslims. Terror Political Violence 2011;23:804-19, doi: http://dx.doi.org/10.1080/09546553.2011.596774.

[10] McCauley C. Psychological issues in understanding terrorism and the response to terrorism. The psychology of terrorism. Wesport, CT: Greenwood Publishing; 2004

[11] McCauley C, Moskalenko S. Mechanisms of political radicalization: pathways toward terrorism. Terror Political Violence 2008;20:415-33, doi:http://dx.doi. org/10.1080/09546550802073367.

[12] Merari Ariel. Terrorism as a strategy of insurgency. Terror Political Violence 19935(4).

[13] Moghaddam FM. The staircase to terrorism: a psychological exploration. Am Psychol 2005;60:161-9, doi:http://dx.doi.org/10.1037/0003-066X.60.2.161.

[14] Moyano M, Trujillo HM. Intention of activism and radicalism among Muslim and Christian youth in a marginal neighbourhood in a Spanish city/Intención de activismo y radicalismo de jóvenes musulmanes y cristianos residentes en un barrio marginal de una ciudad española. Rev Psicol Soc 2014;29:90-120, doi:http://dx.doi.org/10.1080/02134748.2013.878571.

[15] Zagury D. Du deuil de soi à l'idéal en apothéose. Idéal et Cruauté. Editions Lignes; 2015.

[16] Corner E, Gill P. A false dichotomy? Mental illness and lone-actor terrorism. Law Hum Behav 2015:39:23-34, doi:http://dx.doi.org/10.1037/lhb0000102.

[17] Merari A, Diamant I, Bibi A, Broshi Y, Zakin G. Personality characteristics of self Martyrs/Suicide bombers and organizers of suicide attacks. Terror Political Violence 2009;22:87-101, doi:http://dx.doi.org/10.1080/ 09546550903409312 .
[18] Merari Ariel. Driven to death: psychological and social aspects of suicide terrorism. Oxford, UK: Oxford University Press; 2010.

[19] Victoroff J. The mind of the terrorist: a review and critique of psychological approaches. J Confl Resolut 2005;49:3-42, doi:http://dx.doi.org/10.1177/ 0022002704272040.

[20] Victoroff J, Quota S, Adelman JR, Celinska B, Stern N, Wilcox R, Sapolsky RM. Support for religio-political aggression among teenaged boys in Gaza: part I: psychological findings. Aggress Behav 2010;36:219-31, doi:http://dx.doi.org/ 10.1002/ab.20348.

[21] Mccauley C, Scheckter S. What's special about U.S. Muslims? the war on terrorism as seen by Muslims in the United States, Morocco, Egypt, Pakistan, and Indonesia. Stud Confl Terror 2008;31:1024-31, doi:http://dx.doi.org/ $10.1080 / 10576100802400193$

[22] Kruglanski AW, Chen X, Dechesne M, Fishman S, Orehek E. Fully committed: suicide bombers' motivation and the quest for personal significance. Polit Psychol 2009;331-57, doi:http://dx.doi.org/10.1111/j.1467-9221.2009.00698.

[23] Kruglanski AW, Bélanger JJ, Gelfand M, Gunaratna R, Hettiarachchi M, Reinares F, Orehek E, Sasota J, Sharvit K. Terrorism-a (self) love story: redirecting the significance quest can end violence. Am Psychol 2013;68:559-75, doi:http:// dx.doi.org/10.1037/a0032615.

[24] Ministère de l'Intérieur $\mathrm{N}^{\circ} 3922$ - Rapport d'enquête de M. Sébastien Pietrasanta relative aux moyens mis en œuvre par l'Etat pour lutter contre le terrorisme depuis le 7janvier 2015. http://www.assemblee-nationale.fr/14/ rap-enq/r3922.asp. [Accessed 3 December 2017].

[25] Rapport Sénatorial. Projet de loi de finances pour 2017: Protection judiciaire de la jeunesse. 2017 http://www.senat.fr/rap/a16-146-10/a16-146-105.html. [Accessed 6 December 2017].

[26] International Centre for the Study of Radicalisation and Political Violence (ICSR) (2013) ICSR Insight: Up to 11, 000 foreign fighters in Syria; steep rise among Western Europeans/ICSR. In: ICSR. http://icsr.info/2013/12/icsrinsight-11000-foreign-fighters-syria-steep-rise-among-western-europeans/. [Accessed 21 February 2018].

[27] Bazex H, Bénézech M, Mensat J-Y. " Le miroir de la haine ». La prise en charge pénitentiaire de la radicalisation: analyse clinique et criminologique de 112 personnes placées sous main de justice. Ann Med-Psychol Rev Psychiatr 2017;175:276-82, doi:http://dx.doi.org/10.1016/j.amp.2017.01.009.

[28] Rolling J, Corduan G. La radicalisation, un nouveau symptôme adolescent? Neuropsychiatr Enfance Adolesc 2017, doi:http://dx.doi.org/10.1016/j. neurenf.2017.10.002.

[29] Benslama Fethi (2016) Un furieux désir de sacrifice, le surmusulman, Seuil.

[30] Bouzar D, Martin M. Pour quels motifs les jeunes s'engagent-ils dans le djihad? Neuropsychiatr Enfance Adolesc 2016;64:353-9, doi:http://dx.doi.org/ 10.1016/j.neurenf.2016.08.002.

[31] Durkheim Emile. Le Suicide. 1897 France.

[32] Ludot M, Radjack R, Moro MR. «Radicalisation djihadiste» et psychiatrie de l'adolescent. Neuropsychiatr Enfance Adolesc 2016;64:522-8, doi:http://dx. doi.org/10.1016/j.neurenf.2016.08.003.

[33] Bazex H, Mensat J-Y. Qui sont les djihadistes français? Analyse de 12 cas pour contribuer à l'élaboration de profils et à l'évaluation du risque de passage à l'acte. Ann Méd-Psychol Rev Psychiatr 2016;174:257-65.

[34] Thornton LC, Frick PJ, Ray JV, Wall Myers TD, Steinberg L, Cauffman E. Risky sex, drugs, sensation seeking, and callous unemotional traits in justice-involved male adolescents. J Clin Child Adolesc Psychol 2017;53:1-12, doi:http://dx.doi. org/10.1080/15374416.2017.1399398.

[35] Dhami MK, Murray J. Male youth perceptions of violent extremism: towards a test of rational choice theory. Span J Psychol 2016;19:E51, doi:http://dx.doi. org/10.1017/sjp.2016.49.

[36] Leuzinger-Bohleber M. From free speech to IS-pathological regression of some traumatized adolescents from a migrant background in Germany. Int J Appl Psychoanal Stud 2016;13:213-23, doi:http://dx.doi.org/10.1002/aps.1499.

[37] Khosrokhavar F. Les trajectoires des jeunes jihadistes français. . p. 33-44 Études juin.

[38] Kaës R. L'idéologie: l'idéal, l'idée, l'idole. Paris: Dunod; 2016.

[39] Doosje B, Loseman A, van den Bos K. Determinants of radicalization of Islamic youth in the Netherlands: personal uncertainty, perceived injustice, and perceived group threat. J Soc Issues 2013;69:586-604, doi:http://dx.doi.org/ $10.1111 /$ josi.12030

[40] Hogg MA. Uncertainty-identity theory. Advances in experimental social psychology. Academic Press; 2007. p. 69-126.

[41] Hogg MA, Meehan C, Farquharson J. The solace of radicalism: self-uncertainty and group identification in the face of threat. J Exp Soc Psychol 2010;46:10616, doi:http://dx.doi.org/10.1016/j.jesp.2010.05.005.

[42] Schuurman B, Horgan JG. Rationales for terrorist violence in homegrown jihadist groups: a case study from the Netherlands. Aggress Violent Behav 2016;27:55-63, doi:http://dx.doi.org/10.1016/j.avb.2016.02.005.

[43] Dayan J (2015) Crimes de haine. Adolescence T.33 n 3: 613-640. 10.3917/ ado.093.0613.

[44] Van San M, Sieckelinck S, de Winter M. Ideals adrift: an educational approach to radicalization. Ethics Educ 2013;8:276-89, doi:http://dx.doi.org/10.1080/ 17449642.2013.878100.

[45] Bouzar Dounia. A novel motivation-based conceptual framework for disengagement and de-radicalization programs. Sociol Anthropol 2017;5:600-14, doi:http://dx.doi.org/10.13189/sa.2017.050804.

[46] Bouzar, Dounia (2014) 1er Rapport - La métamorphose opérée chez le jeune par les nouveaux discours terroristes -CPDSI. 
[47] Bandura A. Moral disengagement in the perpetration of inhumanities. Personal Soc Psychol Rev 1999;3:193-209, doi:http://dx.doi.org/10.1207/ s15327957pspr0303_3.

[48] Bhui KS, Hicks MH, Lashley M, Jones E. A public health approach to understanding and preventing violent radicalization. BMC Med 2012;10:16, doi:http://dx.doi.org/10.1186/1741-7015-10-16.

[49] Bhui K, Warfa N, Jones E. Is violent radicalisation associated with poverty, migration, poor self-reported health and common mental disorders? PLoS One 2014;9:e90718, doi:http://dx.doi.org/10.1371/journal.pone.0090718.

[50] Bhui K, Everitt B, Jones E. Might depression, psychosocial adversity, and limited social assets explain vulnerability to and resistance against violent radicalisation? PLoS One 2014;9:e105918, doi:http://dx.doi.org/10.1371/ journal.pone.0105918.

[51] Coid JW, Bhui K, MacManus D, Kallis C, Bebbington P, Ullrich S. Extremism, religion and psychiatric morbidity in a population-based sample of young men. Br J Psychiatry J Ment Sci 2016;209:491-7, doi:http://dx.doi.org/10.1192/ bjp.bp.116.186510.

[52] Roy Olivier. Le Djihad et la mort. Paris: Seuil; 2016.

[53] Durkheim Emile. De la division du travail social. Paris: Presses Universitaires de France; 1893.

[54] Bauman Zygmunt. Vivre dans la modernité liquide. Strasbourg: Faculté des Sciences Sociales; 2003.
[55] Doosje B, Moghaddam F, Kruglanski A, De Wolf A, Mann L, Feddes AR Terrorism, radicalization and de-radicalization. Curr Opin Psychol 2016;11:79-84.

[56] Cohen D. Probabilistic epigenesis: an alternative causal model for conduct disorders in children and adolescents. Neurosci Biobehav Rev 2010;34:119-29, doi:http://dx.doi.org/10.1016/j.neubiorev.2009.07.011.

[57] Feddes AR, Mann L, Doosje B. Increasing self-esteem and empathy to prevent violent radicalization: a longitudinal quantitative evaluation of a resilience training focused on adolescents with a dual identity. J Appl Soc Psychol 2015;45:400-11, doi:http://dx.doi.org/10.1111/jasp.12307.

[58] Cabinet du Premier Ministre. MIVILUDES: Mission interministérielle de vigilance et de lutte contre les dérives sectaires. 2015.

[59] Fiske ST. Intergroup biases: a focus on stereotype content. Curr Opin Behav Sci 2015;3:45-50, doi:http://dx.doi.org/10.1016/j.cobeha.2015.01.010.

[60] Botbol M, Campelo N, Lacour-Gonay C. Psychiatrie et Radicalisation- Rapport Intermédiaire du Groupe de Travail de la Fédération Française de Psychiatrie. Pour Rech 2018;93-6 [in press].

[61] Enjolras F. Santé mentale et adolescence. Entre psychiatrie et sciences sociales. Nîmes: Champ social; 2016.

[62] Moskalenko S, McCauley C. Measuring political mobilization: the distinction between activism and radicalism. Terror Political Violence 2009;21:239-60, doi:http://dx.doi.org/10.1080/09546550902765508. 